\title{
THE CAUSAL RELATIONSHIP BETWEEN GOVERNMENT REVENUE AND EXPENDITURE IN SERBIA
}

\author{
Stevan Luković \\ University of Kragujevac, Faculty of Economics, Serbia \\ $\bowtie$ slukovic@kg.ac.rs
}

Milka Grbić

University of Kragujevac, Faculty of Economics, Serbia

$\bowtie$ mgrbic@kg.ac.rs

UDC

336 (497.11)

Original

scientific

paper

Received:

20.01.2014

Accepted:

10.06.2014

\begin{abstract}
This paper studies the causal relationship between government revenue and government expenditure in Serbia, using quarterly data for the 2003 (Q1) - 2012 (Q4) period. In addition to the theoretical arguments regarding this causality, extensive empirical literature is also available. The problem of the fiscal deficit has been a significant burden for the economic system of Serbia for a number of years. Therefore, the relationship between government revenue and government expenditure represents an important issue that should be studied empirically in order to draw certain conclusions. In this paper, the Toda-Yamamoto long-run non-causality method is used to determine whether the causal relationship between government revenue and government expenditure exists in Serbia. The application of this method confirms the existence of a unidirectional (one-way) causality running from government expenditure to government revenue, which means that government expenditure Granger-causes government revenue.
\end{abstract}

Keywords: public revenue, public expenditure, Granger causality test, Toda-Yamamoto method, Serbia

\section{Introduction}

The relationship between government revenue and expenditure has been attracting the attention of economists for a number of years. On the theoretical front, there are several developed theories that explain the causal relationship between government revenues and government expenditures. The first hypothesis is the "revenue-spend" hypothesis, which suggests that changes in 
revenues lead to changes in expenditures. This hypothesis was developed by Friedman (1978) who presumed that rising government revenues lead to an increase in government spending, therefore causing continuously present budget deficit. Therefore, it follows that government has to cut taxes to limit spending (the classic "starve the beast" argument). However, there is another explanation of this hypothesis which works in the case of fiscal illusion, where raising taxes leads to a decrease in government expenditures. Tax increase may make taxpayers hostile toward government spending as they become forced to directly bear the costs. Similarly, tax decreases may lessen the perceived cost of government spending, increasing the quantity demanded (Young, 2009, p. 470). The second hypothesis is the so-called "spend-revenue" hypothesis, which states that the change in government spending causes the growth of government revenues, with causality running from government expenditure to government revenue. This hypothesis was developed by Barro (1979) and Peacock and Wiseman (1979) who argue that government spending is a factor that changes the government revenues, that is, government has first to increase the expenditure, then resultantly revenue is increased (Ali and Shah, 2012, p. 323). The third hypothesis is the "fiscal synchronization" hypothesis, which emphasizes that the government revenues decisions are not independent of government expenditures decisions. On the contrary, these decisions are made simultaneously, which leads to bidirectional causality. This hypothesis was developed by Meltzer and Richard (1981) who state that there is a feedback relationship between government revenues and expenditures and that both of them act interdependently. The fourth hypothesis is the "institutional separation" hypothesis, which argues that government decisions regarding expenditures are independent of decisions regarding government revenues (taxation). According to this hypothesis, government revenues and expenditures are causally independent, i.e. tax rates are posed independently of government spending fluctuations. This hypothesis was developed by Baghestani and McNown (1994), who explain the institutional separation using the argument of the independence of the executive and legislative functions of government (Konukcu-Onal and Tosun, 2008, p. 146).

Each of the above mentioned hypotheses provides the guidance to formulate the policies used for coping with the budget deficits scenario. First, if the "revenue-spend" hypothesis is approved, there are two possible fiscal scenarios. According to believers in conventional tax-spend or "starve the beast", tax cuts are required. Budget deficits cannot be avoided through policies that stimulate government revenues because they would increase government spending as well. Reductions in taxes would, in turn, reduce government expenditures. On the other hand, fiscal illusionists may instead encourage tax increases (especially during times of budget deficits) because they force the public to confront the costs of excessive spending, hopefully decreasing their tolerance for it. Second, if the "spend-revenue" hypothesis holds, the government spends 
first, and pays for it later by raising revenues (Petanlar and Sadeghi, 2012, p. 96). In the long run, this can lead to increased expectations of raising tax rates and the consequent outflow of capital. This hypothesis is valid in situations when expenditures rise due to extraordinary circumstances, such as an economic crisis, where government is forced to raise taxes in the long run. As higher spending now will lead to higher taxes later, this hypothesis suggests that spending decreases are the desired solution to reducing budget deficits (Elyas and Rahimi, 2011, p. 131). Third, if there is a bidirectional causality, i.e. the case of fiscal synchronization, the government revenue decisions are made simultaneously with public spending decisions. In this case, growing budget deficits cannot be resolved by improving only revenue or expenditure side, because both expenditures and revenues push the budget towards equilibrium. In the case of institutional separation, there is no causality between spending and revenue, so changes in government spending do not cause changes in government revenues and vice versa.

Serbia has been facing persistent budget deficits for a long time. Therefore, it seems appropriate to test the causality between government revenue and expenditure. However, on the empirical side, to our knowledge, no research concerning this issue has been conducted in Serbia. Government spending in the long run exceeds government revenues in Serbia and long-lasting consolidated deficit originating from this relationship may be said to represent the most troubling macroeconomic problem Serbian government is facing. Positive consolidated fiscal balance was achieved only in 2005, and from that year budget deficit has been rising every year more and more rapidly. What can be seen from Table 1 is that consolidated public revenues had the same share of GDP in 2012 as in 2005, and that the average share in GDP in the period 20052012 was around $43 \%$. A significant decline in government revenues came as a consequence of global financial crisis and the recessionary trends in the Serbian economy. A significant decrease in the employment rate occurred, which led to the fall in revenues from income taxes and social insurance contributions. The impact of the crisis led to a decline in domestic demand, which reduced value added tax revenue. At the same time, the fact that Serbia is in the process of accession to the European Union required reduction in tariffs on import from the EU. This change also led to the tax revenue drop. As a result of all these changes, a reduction in the fiscal capacity occurred, which, according to some estimates, has been fluctuating around $39 \%$ of GDP in the long run (Arsić, 2010, p. 10). Unlike the consolidated revenues, the share of consolidated public spending in GDP increased significantly, from $41.9 \%$ in 2005 to $48.0 \%$ in 2012. The considerable growth of government spending occurred in 2006. After that, despite the attempts of the state authorities to limit excessive expenditures, the growth trend culminated in 2012 with the consolidated budget deficit exceeding $6 \%$ of GDP. 
Since the space for the considerable increase in tax revenues in the long run is narrowed, it becomes clear that reduction of the budget deficit must be made mostly by reducing government expenditures. The Serbian authorities recognized the severity of the budget deficit issue so that the Fiscal Council created a consolidation framework. In order to reduce the budget deficit by about $3 \%$ of GDP, the Fiscal Council proposed three measures. The first is the tax reform, which would lead to a moderate increase of revenue of around $1 \%$ of GDP, respecting the view that fiscal consolidation must be carried out mainly through government spending. The second measure is "freezing" wages and pensions in the public sector (which would lead to additional budgetary savings in the amount of $1 \%$ of GDP). The third measure is establishing a sustainable system of fiscal decentralization (with additional savings of $0.5-0.7 \%$ of GDP). The rest of the short-term savings (from 0.3 to $0.5 \%$ of GDP) would be achieved by increasing efficiency and rationalization of the state administration (Fiscal Council, 2012, p. 8).

Table 1 The Share of Consolidated Public Revenues and Expenditures in Serbia's GDP, 2005-2012, (in \%)

\begin{tabular}{||c|c|c|c|c|c|c|c|c||}
\hline & 2005 & 2006 & 2007 & 2008 & 2009 & 2010 & 2011 & 2012 \\
\hline $\begin{array}{c}\text { Consolidated } \\
\text { public revenues }\end{array}$ & 43,0 & 44,4 & 44,1 & 42,9 & 42,1 & 42,5 & 41,0 & 41,8 \\
\hline $\begin{array}{c}\text { Consolidated } \\
\text { public } \\
\text { expenditures }\end{array}$ & 41,9 & 45,8 & 46,0 & 45,6 & 46,6 & 47,2 & 46,0 & 48,0 \\
\hline Net balance & 1,1 & $-1,5$ & $-2,0$ & $-2,6$ & $-4,5$ & $-4,7$ & $-5,0$ & $-6,2$ \\
\hline
\end{tabular}

Source: Ministry of Finance of the Republic of Serbia

The aim of this study is to test the validity of the hypotheses of causal relationship between government revenue and government expenditure in the case of Serbia for the period 2003-2012. According to the results of the analysis, some recommendations are provided regarding actions that the authorities should take in the future. The rest of the paper is organized as follows. The second part gives an overview of the most important research dealing with a research question that is in the focus of this paper. The third part concerns the applied methodology and data that are used in the analysis. The final section presents the results of the analysis. Conclusions are given in the final part of the paper.

\section{Review of Literature}

There are numerous studies that investigated the relationship between government revenue and government expenditure in the past few years. Most of these studies use Granger causality test to determine the interdependence of 
government revenues and government expenditures, with some differences in the applied methodology. Looking at the different countries, different researchers have come to different conclusions. Aziz et al. (2000) used TodaYamamoto approach and came to the conclusion regarding the existence of a bidirectional causality between government revenues and expenditures in Malaysia during the period 1960-1990. Fasano and Wang (2002) focused on a sample of GCC countries (Gulf Cooperation Council) for the period 1975-2000 and confirmed the existence of a unidirectional causality running from revenue to expenditure for Bahrain, UAE and Oman, and a bidirectional causality for Saudi Arabia, Kuwait and Qatar. They utilized cointegration and errorcorrection modeling framework which provides a more comprehensive measure of causality than the standard Granger causality test. Konukcu-Onal and Tosun (2008) applied the standard Granger causality test to conclude that in Russia and Belarus the "revenue-spend" hypothesis holds, while for the Kyrgyz Republic and Kazakhstan fiscal synchronization hypothesis is valid. Taha and Loganthan (2008) used the multivariate Granger test on the example of Malaysia and confirmed the existence of a bidirectional causality between direct tax revenues and government spending, indirect tax revenues and government spending, while between non-tax revenues and government spending unidirectional causality exists, running from non-tax revenues to government expenditures. Eita and Mbazima (2008) observed the case of Namibia for the period 19772007. By using the Granger test through cointegration methods of vector autoregression (VAR method), they found a unidirectional causality running from government revenue to government expenditure. Sriyana (2009) studied the relationship of tax revenue and government expenditure in Indonesia for the period 1970-2007, using cointegration test and Vector Error Correction Model (VECM). A unidirectional causality running from tax revenues to government expenditures was proved to exist, which implied a continuous increase in the budget deficit threatening fiscal sustainability in the long term. Sriyana suggested that the government should improve fiscal management to improve the revenue-spend policy. Subhani et al. (2011) used the Bivariate Granger test by applying ARDL model in the case of Pakistan and concluded that the previous lags of tax revenues were causing current government expenditures. Petanlar and Sadeghi (2012) proved the revenue-spend hypothesis in the case of the Petroleum Exporting Countries for the 2000-2009 period, using the P-VAR framework. Focusing on the case of Pakistan, Ali and Shah (2012) used annual data for the period 1976-2009, and showed that there was no long-term or short-term causal relationship between government revenue and government expenditure.

\section{Data and Methodology}

The analysis itself is based on the use of three variables: government revenue (GR), government expenditure (GE) and gross domestic product (Y). 
Gross domestic product is included in the analysis as a third variable because both government revenue and government expenditure are related to the overall economic conditions represented by the GDP ( $\mathrm{Y}$ variable). Moreover, the inclusion of GDP alleviates the problem of spurious causal effects due to the omission of important variables from the investigated relationship (Aziz et al., 2000 , p. 47). For variables GR, GE and Y, quarterly data are used. For variables GR and GE, quarterly data for republic budget receipts and outlays are used, taken from the website of the National Bank of Serbia. The quarterly data for the gross domestic product are taken from the website of the Statistical Office of Serbia. The time period for which the data are collected is 2003-2012, and given the quarterly character of data, we have a total of 40 observations.

Examination of the relationship between government revenue and government expenditure in the case of Serbia is conducted by applying a long run causality test proposed by Toda and Yamamoto (1995). This test was previously applied by Aziz et al. (2000) who used the same variables utilized in this study to investigate the relationship between government revenue and government expenditure in Malaysia. Also, a similar approach was used by Hamdi and Sbia (2013) who focused on a sample of the Gulf Cooperation Council (GCC) countries and explored the causal relationship between government revenues and expenditures.

Granger (1969) developed a relatively simple test that defines causality as follows: the variable $y_{t}$ can be argued to Granger-cause $x_{t}$ if $x_{t}$ can be predicted with greater accuracy by using past values of $y_{t}$ variable than in the case when past values are not used, and all other variables remain unchanged. Given that the standard Granger causality test can be applied to stationary time series, and that the macroeconomic variables are generally nonstationary, a modified procedure of Granger causality test is required.

Toda-Yamamoto Granger non-causality test, as opposed to the standard Granger causality tests, assumes the evaluation of VAR models augmented with additional lags that are defined by the maximum order of integration of time series which are tested for causality. This method is applicable regardless of the order of integration and cointegration rank of the observed variables.

In order to implement the Toda-Yamamoto Granger non-causality method, the starting point refers to the testing of stationarity to determine the order of integration of time series. To test the stationarity of the time series of observed variables, Augmented Dickey-Fuller (ADF) unit root test is used (Dickey and Fuller, 1981). Specifically, we estimate autoregression equation of the form:

$$
\Delta X_{t}=\delta_{0}+\delta_{1} t+\delta_{2} X_{t-1}+\sum_{i=1}^{m} \alpha_{i} \Delta X_{t-i}+\varepsilon_{t}
$$


where: $\mathrm{X}_{\mathrm{t}}$ is the observed variable $\left(\mathrm{GR}_{\mathrm{t}}, \mathrm{GE}_{\mathrm{t}}, \mathrm{Y}_{\mathrm{t}}\right), \mathrm{t}$ is the time trend, $\delta_{0}, \delta_{1}, \delta_{2}, \alpha_{\mathrm{i}}$ stand for a set of parameters that are estimated and $\varepsilon_{\mathrm{t}}$ is a white noise error term. The null hypothesis that the time series has a unit root is tested, i.e. $\mathrm{H}_{0}: \delta_{2}=0$, versus the alternative hypothesis that the time series has no unit root, i.e. $\mathrm{H}_{1}: \delta_{2}$ $<0$. The test is carried out using McKinnon (1996) test statistic at the significance level of $1 \%, 5 \%$ and $10 \%$.

After examining and determining the order of integration, we estimate VAR model to select the optimal lag length to be applied in the model. Then, the augmented VAR model of order $\mathrm{k}+\mathrm{d}_{\max }$ in levels is determined, which in the general case of two variables can be written as:

$$
\begin{gathered}
Y_{t}=\alpha_{0}+\sum_{i=1}^{k+d_{\max }} \alpha_{1 i} Y_{t-i}+\sum_{i=1}^{k+d_{\max }} \delta_{1 i} X_{t-i}+\varepsilon_{Y_{t}} \\
X_{t}=\beta_{0}+\sum_{i=1}^{k+d_{\max }} \beta_{1 i} X_{t-i}+\sum_{j=1}^{k+d_{\max }} \varphi_{1 i} Y_{t-i}+\varepsilon_{X_{t}}
\end{gathered}
$$

where: $\alpha_{0}$ and $\beta_{0}$ are constants, $X$ and $Y$ are variables of interest, $\alpha_{1 \mathrm{i}}, \delta_{1 \mathrm{i}}, \beta_{1 \mathrm{i}}$ and $\varphi_{1 i}$ are the model parameters, $\mathrm{k}$ is the optimal lag length in the original VAR system, $d_{\max }$ is the maximum order of integration of variables in the VAR system, and $\varepsilon_{\mathrm{Yt}}$ and $\varepsilon_{\mathrm{Xt}}$ are random errors with characteristics of white noise.

Finally, to test the significance of parameters of the VAR $\left(k+d_{\max }\right)$ model, the Wald test is applied (also known as the modified Wald or MWald). From the equation (2a), the hypothesis " $\mathrm{X}$ does not Granger-cause $\mathrm{Y}$ " is tested, i.e. $\mathrm{H}_{0}: \delta_{1 \mathrm{i}}=0$ versus $\mathrm{H}_{1}: \delta_{1 \mathrm{i}} \neq 0$, (i $\left.=1 \ldots \mathrm{k}\right)$. Similarly, from the equation $(2 \mathrm{~b})$, the hypothesis " $\mathrm{Y}$ does not Granger-cause $\mathrm{X}$ " is tested, i.e., $\mathrm{H}_{0}: \varphi_{1 \mathrm{i}}=0$ versus $\mathrm{H}_{1}$ : $\varphi_{1 i} \neq 0,(i=1 \ldots k)$. Wald test is applied to the first $\mathrm{k}$ coefficient matrices, while the coefficients of the last $d_{\max }$ parameters of the model matrix are ignored (they are considered to be zero). In this case, the Wald test statistic follows asymptotic $\lambda^{2}$ distribution and can be applied either to $X_{t}$ and $Y_{t}, I(0), I(1)$ or $\mathrm{I}(2)$, cointegrated or noncointegrated, provided that the order of integration does not exceed the exact lag length in the model (Toda and Yamamoto, 1995). Rambaldi and Doran (1996) have shown that the MWald tests for Granger noncausality testing are even more effective when the Seemingly Unrelated Regression (SUR) models are used in the evaluation.

\section{Empirical Results}

The results of the ADF test of unit root are shown in Table 2 for the model with a constant and trend included and a model when only a constant is included. The null hypothesis that the time series has a unit root is rejected for the variable $\operatorname{GDP}(\mathrm{Y})$, indicating that this time series is stationary in levels. For 
variables government revenues (GR) and government expenditure (GE), the null hypothesis cannot be rejected, which means that these variables have a unit root in levels. Afterwards, the stationarity of the first differences of the variables GR and GE is tested. Based on the results of the unit root test, the null hypothesis is rejected. Therefore, it can be concluded that the time series of GR and GE are integrated of order one, i.e., I (1), that is, non-stationary in levels and stationary in the first differences.

Table 2: Results of the ADF Unit Root Test

\begin{tabular}{||c|c|c|}
\hline \multicolumn{3}{|c|}{ at Level } \\
\hline Variables & Constant, With trend (k) & $\begin{array}{c}\text { Constant, No trend } \\
(\mathbf{k})\end{array}$ \\
\hline GR & $-1.784192(1)$ & $-2.308685(1)$ \\
\hline GE & $-2.270650(1)$ & $-1.386642(1)$ \\
\hline Y & $-1.033183(1)$ & $-4.030163^{*}(0)$ \\
\hline \multicolumn{3}{|c|}{ At $1^{\text {st }}$ Difference } \\
\hline Variables & Constant, With trend (k) & $\begin{array}{c}\text { Constant, No trend } \\
(\mathbf{k})\end{array}$ \\
\hline$\Delta \mathrm{GR}$ & $-11.07971^{*}(0)$ & $-10.67565^{*}(0)$ \\
\hline$\Delta \mathrm{GE}$ & $-10.12030^{*}(0)$ & $-10.10032^{*}(0)$ \\
\hline
\end{tabular}

Note: the number of lags (k) in model is determined by Schwarz information criterion (SIC).

Asterisk $(*)$ denotes statistically significant values at $1 \%$ level.

Source: Authors' calculations

When we know that 2 out of 3 variables are integrated of order one, i.e. I (1), then the VAR model can be set using all variables regardless of the order of integration in time series. In this case, the optimal lag length in VAR model is selected based on several selection criteria, as shown in Table 3 .

Table 3: Lags Using Different Criteria for Trivariate VAR Model

\begin{tabular}{|c|c|c|c|c|c||}
\hline \hline Lag & LR & FPE & AIC & SC & HQ \\
\hline 0 & NA & $1.90 \mathrm{e}-06$ & -4.662051 & -4.531436 & -4.616003 \\
\hline 1 & $216.9877 *$ & $4.31 \mathrm{e}-09$ & -10.75095 & $-10.22849^{*}$ & $-10.56676^{*}$ \\
\hline 2 & 15.33540 & $4.25 \mathrm{e}-09 *$ & $-10.77564^{*}$ & -9.861340 & -10.45331 \\
\hline 3 & 8.809306 & $5.13 \mathrm{e}-09$ & -10.61543 & -9.309279 & -10.15495 \\
\hline
\end{tabular}

Notes: * indicates lag order selected by the criterion; LR: sequential modified LR test statistic (each test at 5\% level), FPE: Final prediction error, AIC: Akaike information criterion, SC: Schwarz information criterion, HQ: Hannan-Quinn information criterion Source: Authors' calculations 
According to these estimates, sequential modified LR test statistic (LR), Schwarz information criterion (SIC) and Hannan-Quinn information criterion (HQ) show that the optimal lag length is 1 , whereas the final prediction error (FPE) and the Akaike information criterion (AIC) show that the optimal lag length is 2 . However, after testing serial correlation in the model, we proceed with the optimal lag length 2 .

Since we know the order of integration of the variables, that is, $d_{\max }=1$, as well as the optimal lag length, that is, $\mathrm{k}=2$, the specification of VAR model follows, consisting of three variables in levels of order $\mathrm{k}+\mathrm{d}_{\max }=1+2=3$. Using the framework of Seemingly Unrelated Regression (SUR), we estimate VAR (3) as follows:

$$
\left[\begin{array}{l}
G R_{t} \\
G E_{t} \\
Y_{t}
\end{array}\right]=A_{0}+A_{1}\left[\begin{array}{l}
G R_{t-1} \\
G E_{t-1} \\
Y_{t-1}
\end{array}\right]+A_{2}\left[\begin{array}{l}
G R_{t-2} \\
G E_{t-2} \\
Y_{t-2}
\end{array}\right]+A_{3}\left[\begin{array}{l}
G R_{t-3} \\
G E_{t-3} \\
Y_{t-3}
\end{array}\right]+\left[\begin{array}{l}
e_{G R} \\
e_{G E} \\
e_{Y}
\end{array}\right]
$$

where $\mathrm{A}_{0}$ is the intercept vector and the $\mathrm{e}_{\mathrm{GR}}, \mathrm{e}_{\mathrm{GE}}$ and $\mathrm{e}_{\mathrm{Y}}$ are error terms. Finally, in order to identify causal relationships between the observed variables, testing of the limitations of the model parameters follows. To test that GE does not Granger-cause GR, the null hypothesis would be $\mathrm{H}_{0}: \mathrm{a}_{12}{ }^{(1)}=\mathrm{a}_{12}{ }^{(2)}=0$, where $a_{12}{ }^{(i)}, i=1,2$ are the coefficients next to GE appearing in the first equation of the system (3). Similarly, when we check that GR does not Granger cause GE, the null hypothesis would be $\mathrm{H}_{0}: \mathrm{a}_{21}{ }^{(1)}=\mathrm{a}_{21}{ }^{(2)}=0$, where $\mathrm{a}_{21}{ }^{(\mathrm{i})}, \mathrm{i}=1,2$, are the coefficients of the GR that appear in the second equation in the system (3). The existence of causality is confirmed by the rejection of the null hypothesis when the value of the MWald test statistic is statistically significant at the $1 \%, 5 \%$ or $10 \%$ significance level. The test results of the trivariate VAR (3) model are shown in Table 4.

Table 4.Toda-Yamamoto Granger Non-Causality Test Results

\begin{tabular}{||c|c|c|c|}
\hline Null Hypothesis & $\mathrm{k}+\mathrm{d}_{\max }$ & MWald Statistics & $\mathrm{p}$-values \\
\hline $\begin{array}{c}\text { GE does not Granger- } \\
\text { cause GR }\end{array}$ & & $6.586477^{* *}$ & $\mathbf{0 . 0 3 7 1}$ \\
\cline { 1 - 1 } $\begin{array}{c}\text { GR does not Granger- } \\
\text { cause GE }\end{array}$ & $2+1=3$ & 4.309615 & 0.1159 \\
\cline { 3 - 4 } & &
\end{tabular}

Asterisks (**) denote statistically significant values at $5 \%$ level.

Source: Authors' calculations

The results presented in Table 4 point to the existence of a unidirectional causality running from government expenditure to government revenue at 5\% significance level, since p-value equals 0.0371 is lower than significance level 
$\alpha=0.05$, which means that enough statistical evidence exists to accept alternative hypothesis. In other words, the spend-revenue hypothesis holds, that is, government expenditures Granger cause government revenues. On the other hand, the null hypothesis that GR does not Granger-cause GE cannot be rejected at the significance level of $5 \%$ (because $p$ value is higher than $\alpha=0.05$ ) which means that a causal relationship in the sense of Granger causality running from government revenue to government expenditure does not exist.

\section{Final remarks}

The procedure conducted using Toda-Yamamoto approach has shown that there is enough statistical evidence pointing to the existence of a unidirectional causal relationship between government expenditures and revenues in Serbia, running from government expenditure to government revenue. This relationship was confirmed on the basis of the data for the period 2003-2012. Nevertheless, the possibility that the use of an extended time period or alternative statistical procedures could generate different results is not excluded. Accordingly, future government efforts to cut government spending included in the consolidation propositions seem to be justified, since the analysis conducted in this paper indicates that it is the optimal way to reduce the budget deficit in the long run. Any increase in state spending in line with the spend-revenue hypothesis leads to an increase in government revenues in the long run, that is, an increase of tax rates. However, since the taxation capacity in Serbia in the medium and long run is limited, it appears that further increase in government spending is not sustainable. Therefore, the only solution to budget deficit in the case of Serbia is a decrease in government spending.

\section{Acknowledgements}

This paper is a part of research project No. 41010, financed by the Ministry of Science and Technological Development of the Republic of Serbia

\section{References}

Ali, R., Shah, M. (2012) "The Causal Relationship Between Governement Expenditure and Revenue in Pakistan", Interdisciplinary Journal of Contemporary Research in Business, 3(12): 323-329

Arsić, M. (2010) Fiskalna konsolidacija i reforma javnog sektora, Poreska politika u Srbiji-Pogled unapred, USAID Sega Projekat, pp. 9-21

Aziz, A. M. et al. (2000) "Testing for Causality Between Taxation and Government Spending: An Application of Toda-Yamamoto Approach“, Pertanika Journal of Social Science and Humanities, 8(1): 45-50 
Dickey, D. A., Fuller, W. A. (1981) "Likelihood Ratio Statistics for Autoregressive Time Series with a Unit Root", Econometrica, 49 (4): 1057-1072

Eita, J. H., Mbazima, D. (2008), "The Causal Relationship Between Government Revenue and Expenditure in Namibia", Munich Personal RePEc Archive, Paper No. 9154

Elyasi, Y., Rahimi, M. (2011) "The Causality between Government Revenue and Government Expenditure in Iran", International Journal of Economic Sciences and Applied Research, 5(1): 129-145

Fasano, U., Wang, Q. (2002) "Testing the Relationship Between Government Spending and Revenue: Evidence form GCC Countries", IMF Working Paper, WP/02/201

Fiscal Council of the Republic of Serbia (2012) Proposed Fiscal Consolidation Measures 2012-2016, Belgrade, available at http://fiskalnisavet.rs/images/izvestaji/_ fiscal_consolidation_2012-2016complete_report.pdf

Granger, C. W. J. (1969) "Investigating Causal Relations by Econometric Models and Cross-spectral Methods", Econometrica, 37(3), 424-438

Hamdi, H., Sbia, R. (2013) "Re-Examining Government Revenues, Government Spending and Economic Growth in GCC Countries", The Journal of Apllied Business Research, 29 (3): 737-742

Konukcu-Onal, D., Tosun, A.N. (2008) Government Revenue-Expenditure Nexus: Evidence from Several Transitional Economies, Ekonomski Anali, 53 (178-179): $145-156$

Petanlar, S.E., Sadeghi, S. (2012) "Relationship Between Government Spending and Revenue: Evidence From Oil Exporting Countries", International Journal of Economics and Management Engineeering, 2 (2): 95-97

Rambaldi, A. N., Doran, H. E. (1996) "Testing for Granger Non-Causality in Cointegrated Systems Made Easy", Working Paper in Econometrics and Applied Statistics, No. 88, University of New England

Sriyana, J. (2009) "A Causality Relationship Between Tax Revenue and Government Expenditure in Indonesia", Economic Journal of Emerging Markets, 1(2): 93-101

Subhani, M. I. et al. (2012) "An Investigation of Granger Causality Between Tax Revenues and Government Expenditures", European Journal of Scientific Research, 68 (3): 340-344

Taha, R., Loganathan, N. (2008) "Causality Between Tax Revenue and Government Spending in Malaysia", The International Journal of Business and Finance Research, 2 (2): 63-73

Toda, H. Y., Yamamoto, T. (1995) "Statistical inferences in vector autoregressions with possibly integrated processes", Journal of Econometrics, 66(1-2): 225-250

Young, A. (2009) “Tax-Spend or Fiscal Illusion”, CATO Journal, 29 (3): 469-485 


\title{
TESTIRANJE POVEZANOSTI DRŽAVNIH PRIHODA I DRŽAVNIH RASHODA U SRBIJI
}

\begin{abstract}
Apstrakt: Ovaj rad izučava relaciju između državnih prihoda i državnih rashoda u Srbiji, korišćenjem kvartalnih podataka za period 2003(Q1)2012(Q4). Pored teorijske argumentacije razvijene o ovoj relaciji, obimna empirijska literatura je takođe dostupna. Problem fiskalnog deficita već duži niz godina predstavlja značajno opterećenje za ekonomski sistem Srbije, pa je odnos državnih prihoda i državnih rashoda važno pitanje koje treba empirijski izučiti i izvesti određene zaključke. U ovom radu, korišćen je TodaYamamoto metod testiranja uzročnosti u cilju utvrđivanja da li postoji kauzalna veza između državnih prihoda i državnih rashoda u Srbiji. Primenom ovog metoda je pokazano da postoji jednosmerna uzročnoposledična veza, i to u smeru od državnih rashoda ka državnim prihodima, što znači da državni rashodi uzrokuju državne prihode u smislu Grejndžera.
\end{abstract}

Ključne reči: državni prihodi, državni rashodi, Grejndžerov test uzročnosti, Toda-Yamamoto metod, Srbija. 